Covered in: Erih Plus; HeinOnline; CEEOL; RePEC; CrossRef; Google Scholar; KVK; WorldCat; ICI Journals Master List - Index Copernicus; EBSCO

2021, Volume 8, Issue 1, pages: 61-69| https://doi.org/10.18662/eljpa/8.1/149

\section{Study on the}

Management of the Domestic Sanitation Service in the

\section{Commune of Bosanci, Suceava County}

Irina BILOUSEAC 1 , Ana - Maria CROITOR ${ }^{2}$

${ }^{1}$ Associate Professor PhD, "Ştefan cel Mare" University of Suceava, Faculty of Law and Administrative Sciences, Suceava, Romania irina.bilouseac@,fdsa.usv.ro

2 Bachelor's Graduate, "Ştefan cel Mare" University of Suceava, Faculty of Law and Administrative Sciences, Suceava, Romania info.annette@yahoo.com
Abstract: In Romania, the management of public utility services is organized and performed in the following forms: direct management or indirect management or delegated management. In this article we have chosen as a model the public sanitation service in the commune of Bosanci and we want to highlight what is the best way to optimize this service, in direct management or delegated management. The public sanitation service in Bosanci is a public service that has been provided over time through both forms of management. The inhabitants of Bosanci were provided with the sanitation service both in direct management and in delegated management, respectively until the end of 2018 in delegated management, and starting with 2019 in direct management, and in order to highlight the advantages and disadvantages of each form we will present comparatively the way in which the domestic sanitation service was provided, which currently benefits 7400 inhabitants.

Keywords: quality and performance of the public service, sanitation service, decentralization in public services, direct management, delegated management.

How to cite: Bilouseac, I., \& Croitor, A.-M. (2021). Study on the Management of the Domestic Sanitation Service in the Commune of Bosanci, Suceava County. European Journal of Law and Public Administration, 8(1), 61-69. https://doi.org/10.18662/eljpa/8.1/149 


\section{Introduction}

The present comparative study was elaborated in order to highlight which of the forms of management of the sanitation service (direct or delegated management (Romanian Government, 2019, Title III, art. 590592) is more efficient and which best meets the needs of the citizens of Bosanci, Suceava County, starting from the way of achievement, number of resources used, performance indicators, up to advantages and disadvantages. The sanitation service is part of the category of community public utility services. From the collection, transport and storage of waste to the cleaning, maintenance of public roads and the maintenance of traffic on them in bad weather (frost or frost), all these are part of the vital / fundamental needs that underlie the quality of life of members of Bosanci. We also want to highlight the best way to optimize the sanitation service and its convergence to European quality standards, so that the standard of living of the inhabitants of Bosanci be constantly improved and in line with European Union standards.

\section{Organization and operation of the sanitation service in the commune of Bosanci in the two forms of management}

The inhabitants of Bosanci were provided with the sanitation service both in direct management and in delegated management.

Until 2019, the sanitation service was provided under delegated management, in which case the Bosanci Town Hall, which established the sanitation service, decided to fully entrust the provision of this service to an economic operator, based on a management delegation contract (Dincă, 2008). During the period when the service was provided under delegated management, the number of inhabitants varied between 6719-7400, and the frequency of garbage collection was as follows:

- Once every two weeks in the cold season;

- Once a week in the warm season.

Over time, the waste was stored in several places, the Town Hall having no control over the collection and storage of waste collected from the commune of Bosanci. 
The economic operator was authorized to collect the following categories of waste: household waste, street waste, waste assimilated to household waste, and their transport was carried out only with specialized and authorized vehicles.

Starting with 2019, the sanitation service in Bosanci was provided to the inhabitants under direct management, a situation in which the mayor together with the Local Council, in the name and as representatives of the commune of Bosanci, assumed all the responsibilities and competencies they returned regarding the provision of the sanitation service(Chirleşan et al., 2001). As the management of a service can be performed only by an NRACS licensed operator, the Bosanci Local Sanitation Service had the obligation to request from NRACS the license to provide the service, within 90 days from the date of adoption by the Local Council of the decision to give in administration.

At a number of 7400 inhabitants with 2100 individual households the frequency of waste collection is as follows:

- Once every two weeks in the cold season;

- Once a week in the warm season.

The collected waste is deposited at the Moara point. The Bosanci Local Sanitation Service is authorized to collect the following categories of waste: household waste, street waste, waste assimilated to household waste.

The collection of the collected waste is carried out only with specialized and authorized means of transport, in accordance with the legislation in force.

We can see that the way of performing the sanitation service in the commune of Bosanci, in terms of frequency of waste collection is the same both for the period when the service was provided under delegated management by an economic operator, but also during which the Town Hall has chosen to provide this service under direct management, although the number of inhabitants has increased. 
Study on the Management of the Domestic Sanitation Service in the Commune... Irina BILOUSEAC \& Ana-Maria CROITOR

Table 1. Resources used to provide the service

\begin{tabular}{|c|c|}
\hline $\begin{array}{l}\text { Resources used to provide } \\
\text { the service in direct management }\end{array}$ & $\begin{array}{l}\text { Resources used to provide } \\
\text { the service in delegated } \\
\text { management }\end{array}$ \\
\hline $\begin{array}{ll} & \text { Human resources: } \\
- & \text { Head of service; } \\
- & 1 \text { bulldoexcavator driver; } \\
- & 1 \text { garbage truck driver; } \\
- & 2 \text { unskilled workers; } \\
- & 1 \text { cashier. } \\
\end{array}$ & $\begin{array}{c}\text { Human resources: } \\
\text { - } 1 \text { garbage truck driver; } \\
-\quad 2 \text { unskilled workers. }\end{array}$ \\
\hline \begin{tabular}{ll} 
& \multicolumn{1}{c}{ Specific cars: } \\
- & 1 compactor garbage truck; \\
- & 1 bulldoexcavator CASE 595 SLE; \\
- & 2 vans; \\
- & A 100 HP tractor; \\
- & 1 compact crawler excavator; \\
- & 1 tipper trailer; \\
- & 1 fertilizer distributor.
\end{tabular} & $\begin{array}{ll} & \text { Specific cars: } \\
- & 1 \text { compactor garbage truck; } \\
- & 1 \text { van; } \\
- & 1 \text { fertilizer distributor. }\end{array}$ \\
\hline $\begin{array}{l}\quad \text { Pre-collection containers: } \\
-\quad 30 \text { metal eurocontainers of } 10001 ; \\
-\quad 40 \text { street garbage bins. }\end{array}$ & - \\
\hline
\end{tabular}

Source: author's own conception based on internal data from the Town Hall of Bosanci, Suceava County, accessed on 20.03.2021

In the case of direct management, the number of resources is higher, compared to the period when the service was provided in delegated management. In terms of human resources, in the organizational chart of the Bosanci Local Sanitation Service, in addition to 2 drivers and 2 unskilled workers, there is a head of service and a cashier, the material resources and the specific cars are also in greater numbers, some of these being purchased from the local budget, others through a project financed by EAFRD in order to equip and modernize the public sanitation service ${ }^{1}$. In the case of delegated management, the staff structure that the economic operator makes available for the provision of the service was smaller, and the material resources were smaller.

\footnotetext{
${ }^{1}$ Internal Sources from the Town Hall of the commune of Bosanci, Suceava County
} 
We will further analyze the quantities of waste that were collected and stored at the Moara site, for a year, when the service was provided in delegated management and now, when it is provided in direct management

Table 2. Quantities of deposited waste

\begin{tabular}{c|cc|cc}
\hline \multirow{2}{*}{ Month } & \multicolumn{2}{|c|}{$\begin{array}{c}\text { Direct management } \\
\text { Year 2019 }\end{array}$} & \multicolumn{2}{c}{$\begin{array}{c}\text { Delegated } \\
\text { management } \\
\text { Year 2018 }\end{array}$} \\
\cline { 2 - 5 } & \multicolumn{2}{|c|}{ Amount } & \multicolumn{2}{|c}{ Amount } \\
$\mathrm{m}^{3}$ & tons & $\mathrm{m}^{3}$ & tons \\
\hline January & 199 & 60,012 & 229 & 102,71 \\
February & 190 & 63,85 & 255 & 82,652 \\
March & 192 & 76,299 & 200 & 93,123 \\
April & 255 & 69,122 & 199 & 73,542 \\
May & 200 & 79,593 & 200 & 93,123 \\
June & 208 & 82,96 & 200 & 82,96 \\
July & 229 & 89,18 & 190 & 77,38 \\
August & 272 & 75,97 & 229 & 81,30 \\
September & 272 & 89,5 & 272 & 103,03 \\
October & 228 & 81,76 & 228 & 95,29 \\
November & 176,5 & 61,74 & 205 & 69,3 \\
December & 205 & 67,3 & 205 & 80,83 \\
\hline
\end{tabular}

Source: author's own conception based on internal data from the Town Hall of Bosanci, Suceava County, accessed on 20.03.2021

As can be seen, in terms of delegated management, the quantities of waste stored are higher. According to the data provided by Bosanci Town Hall, the collection and transport costs are quite high, about 450 lei/ton, and the storage cost is 120 lei / ton, therefore the operator will always be interested in having as much as possible waste to increase its profit, while under direct management, the Town Hall having control and decisionmaking power over the service can control the amount of waste because its 
interest is not to make a profit but to ensure access to as many citizens as possible to a quality and affordable service.

If we refer to another indicator of the sanitation service, namely the price of this service, we notice differences when the sanitation service is provided in the two forms of management.

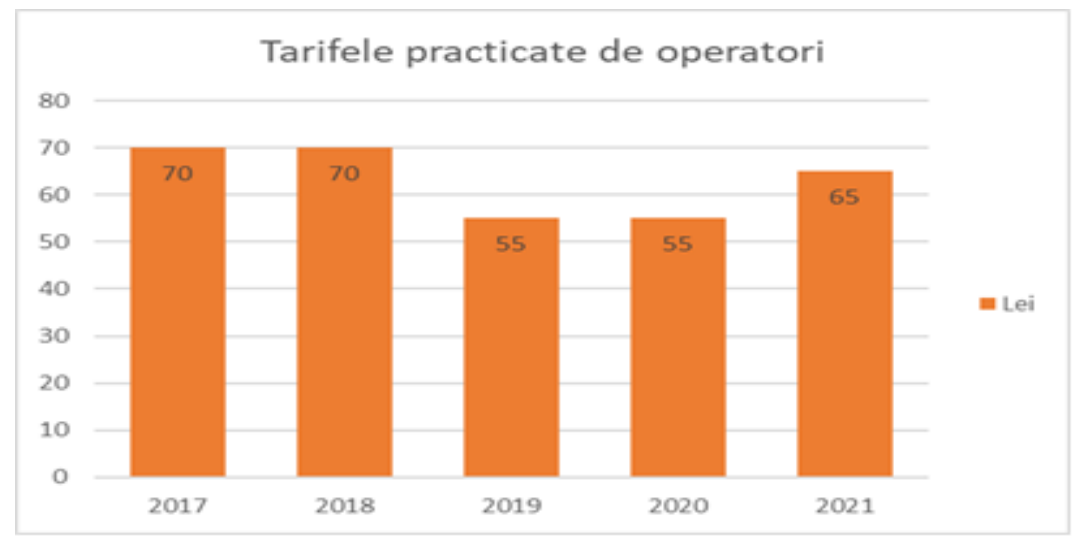

Fig. 1. Evolution of the sanitation service tariff in the period 2017-2021 Source: Internal Data from the Town Hall of Bosanci, Suceava County, accessed on 20.03.2021

Over the years the value of the tariff has fluctuated. It can be observed that in the period 2017-2018 the tariff was the highest, respectively 70 lei per person, during this period the sanitation service was provided under delegated management. Starting with 2019, the service was provided under direct management, and the tariff decreased to 55 lei per person. In 2021 the tariff increased to 65 lei per person, was higher than in 2019-2020, but lower than in 2017-2018.

\section{The advantages of the two forms of management in providing the sanitation service in the commune of Bosanci}

Therefore, the public sanitation service in the commune of Bosanci has been provided over time through both forms of management, direct management or delegated management. Each of the two forms has advantages, which we try to summarize in the table below. 
Table 3. Avantages of the forms of management of the sanitation service

\begin{tabular}{|c|c|}
\hline $\begin{array}{l}\text { Form of } \\
\text { management }\end{array}$ & Advantages \\
\hline Direct & $\begin{array}{l}\text { - the population benefits from a reduction of the tariff by } 19 \% \text {; } \\
\text { - citizens benefit from a direct contracting of the service; } \\
\text { - because all the receipts go through the accounts of the Town } \\
\text { Hall, it can manage its investment alone; } \\
\text { - the possibility of supporting of the poor population by the } \\
\text { local public authority; } \\
\text { - access to the Communitary non-reimbursable funds for } \\
\text { public authorities tht allow certain investments to be made; } \\
\text {-increasing the local budget; } \\
\text { - maintaining the authority of the Local Council over the } \\
\text { specific activities of the service; } \\
\text { - the Town Hall can apply the policies it wants; } \\
\text { - the Town Hall has total control and decision-making power } \\
\text { over the service; } \\
\text {-improving the quality of life of the inhabitants by providing a } \\
\text { qualitative and affordable service; } \\
\text {-infrastructure development; } \\
\text {-protecting the environment by using low-pollution } \\
\text { equipment. }\end{array}$ \\
\hline Delegated & $\begin{array}{l}\text { - the Town Hall is financially discharged from the sanitation } \\
\text { service; } \\
\text { - the necessary investment regarding the service falls under the } \\
\text { responsibilities of the operator; } \\
\text { - the Town Hall will act as supervisor of the operator's } \\
\text { compliance with the requirements imposed in the contract; } \\
\text {-the Town Hall will have the right to final control over the } \\
\text { service; } \\
\text { - the Town Hall has the possibility to cancel the delegation of } \\
\text { management in case the operator has a defective activity. }\end{array}$ \\
\hline
\end{tabular}

Source: Authors' own conception

As can be seen, each form of management has both advantages and disadvantages. When the local public authority has the resources necessary for the direct management of the service, the population benefits from a quality and at the same time affordable service, the local authority can apply the policies it wants, and last but not least, the local authority can make substantial annual savings by passing all the proceeds through its accounts, 
so that these savings can be directed to other investments that add value to the local community.

But also during the period when the local authority transferred all the attributions and responsibilities regarding the provision of the public sanitation service there were certain benefits such as the fact that the Town Hall was financially discharged from the sanitation service, and the investments necessary for the service fell within the operator's responsibilities. In this situation, the Town Hall kept the attributions of final control over the performance of the service with the possibility to cancel the delegation of management in case the operator had persistently defective activity. Regardless of the form of management that the local public authority chooses, it will have to take into account the satisfaction of the general interests of the human community.

\section{Conclusions}

Public services represent the way in which the public administration puts itself at the service of the citizens; the functioning of the local public services in Romania depends on the efficiency of the use of human, financial and material resources by the local public administration authorities. That being said, human resources, i.e. civil servants who work locally, determine the level of satisfaction of the local community through the quality of public services provided.

Both forms of management have advantages and disadvantages. Regarding the management of the sanitation service of the commune of Bosanci, we appreciate that maintaining its direct management ensures the possibility of development and modernization, guarantees the maintenance of the authority of the Local Council over it, ensures a high degree of affordability in terms of tariff and also ensures the citizens' participation to improve the activity of the service. In addition to the benefits enjoyed by the community, the Town Hall has two major benefits, firstly access to nonreimbursable community funds for public authorities, secondly the fact that all proceeds go through its accounts, so the Town Hall decides to manage allocation of funds for future investments. 
Considering the analysis performed on the situation of the domestic sanitation service in the period 2017-2020, it is obvious that maintaining the direct management of the service through a Sanitation Service organized under the Local Council is the optimal solution for obtaining the best quality/cost ratio.

\section{References}

Chirleşan, D., Prodan, A., Brăileanu, T., Manolescu, I., \& Grigoruță, V. M. (2001). Management in administratie [Management in administration]. Sedcom Libris Publishing House.

Dincă, D. (2008). Servicii publice si dezvoltare locală [Public services and local development]. Lumina Lex Publishing House.

Romanian Government. (2019). Ordonanta de urgenta nr. 57 din 3 iulie 2019, privind Codul administrativ [Government Emergency Ordinance no. 67/2019 regarding Administrative code]. Monitorul Oficial, 555, 5 Iulie 2019 [Official Gazette of Romania, no. 555 on July 5, 2019]. http://legislatie.just.ro/Public/DetaliiDocumentAfis/215925 